https://nv.nltu.edu.ua

https://doi.org/10.36930/40300303

$@ \bigotimes$ Correspondence author

Article received 26.03.2020 p.

D. I. Bidolakh

Article accepted 04.06.2020 p.

dimbid@ukr.net

UDC 712.253.003.12:657.371[477.63]

В. С. Кузьович, Д. І. Бідолах, С. М. Підховна, О. Б. Тиманська, Ю. Г. Гринюк

ВП НУБіП України "Бережанський агротехнічний інститут", м. Бережани, Украйна

\title{
ВПОРЯДКУВАННЯ ЗЕЛЕНИХ НАСАДЖЕНЬ ТА БЛАГОУСТРІЙ ТЕРИТОРІЇ ЛАНОВЕЦЬКОГО ЗООБОТСАДУ В ТЕРНОПІЛЬСЬКІЙ ОБЛАСТІ
}

\begin{abstract}
Наведено результати проведення інвентаризації деревно-кущових рослин Лановецького зооботсаду із застосуванням сучасного інструментарію (використання даних GPS-інвентаризації, відкоригованих за матеріалами дистанційного зондування в геоінформаційних системах з моделюванням та тривимірною візуалізацією у програмах комп'ютерного проектування). Встановлено та проаналізовано видовий склад насаджень об'єкта дослідження, наведено його фітосанітарну, естетичну та якісну характеристики, визначено типи садово-паркових ландшафтів зооботсаду. За результатами таксаційної інвентаризації зелених насаджень зоологічного парку "Лановецький зооботсад" виявлено 69 видів і форм дендрофлори. Як свідчать дані фітосанітарного стану деревної рослинності, переважна кількість дерев належить до категорій стану "добрий" (55\% від загальної кількості рослин), "задовільний" (23\%) або "незадовільний" (22\%). Показник життєвого стану деревостану, з огляду на кількісні характеристики дерев парку, становить $84 \%$, що відповідає оцінці "добре". Серед деревних насаджень парку виявлено 324 дерева із фаутами (15,5\% від усіх дерев). Виконано аналіз тваринного світу зоологічної частини ботсаду. Розроблено проектні пропозиції щодо ландшафтно-архітектурного оформлення території зооботсаду у вигляді картографічних матеріалів та тривимірного макету у комп'ютерній програмі Realtime Lamdscaping Architect 16. Створення електронного макету-основи території з нанесеною деревно-кущовою рослинністю дало змогу змоделювати у комп'ютерній програмі часові зміни та перетворення внаслідок реконструкції зоологічного парку. Опрацьовано нові підходи щодо способів проведення комплексної оцінки ландшафтно-планувальної структури території. Проаналізувавши стан зелених насаджень на території об'єкта, з'ясовано, що на сьогодні потрібно здійснити комплекс заходів щодо відновлення естетичного вигляду насаджень, забезпечити належний рівень подальшого їх функціонування та створити нові декоративні деревно-кущові та квітникові композиції.
\end{abstract}

Ключові слова: інвентаризація; тривимірний макет насаджень; зооботсад.

\section{Вступ}

Зоологічний сад - це природоохоронний, науководослідний і культурно-освітній об'єкт, що виступає в ролі своєрідного "живого музею", який створює та доглядає людина для охорони та примноження біорізноманіття і має науково-просвітницьке значення. Такий підхід до охорони природи застосовують для провадження еколого-виховної роботи, побудови експозицій, що включають місцеві, а також рідкісні та екзотичні види флори і фауни, збереження для майбутніх поколінь їх генофонду та дає змогу вивчати і робити висновки щодо життєдіяльності рослин і тварин в умовах неволі. Зоологічні парки є об'єктами природно-заповідного фонду України.
Внесок зоологічних і ботанічних парків у збереження рослинного і тваринного світу є досить значним. Адже, завдячуючи таким об'єктам для майбутніх поколінь, збережено такі рідкісні види фауни, які навіть вважають зниклими в умовах дикої природи. До таких тварин віднесено зубрів, білих антилоп, коней Пржевальського, оленів Давида, гавайських казарок та інших. Деякі держави навіть утворюють спеціальні центри реабілітації тварин, де постійно надають допомогу пораненим та хворим видам.

Лановецький зоологічний парк є антропогенно зміненим природним середовищем, що призначене для сімейного дозвілля мешканців міста, їх гостей та інших відвідувачів. На сьогодні цей парк перебуває у незадовільному стані та потребує здійснення низки госпо-

Інформація про автора:

Кузьович Василь Степанович, канд. с.-г. наук, доцент, завідувач кафедри лісового та садово-паркового господарства. Email: vasyl.kuzovych@gmail.com

Бідолах Дмитро Ілліч, канд. с.-г. наук, доцент, кафедра лісового та садово-паркового господарства. Email: dimbid@ukr.net; https://orcid.org/0000-0003-0248-3731

Підховна Світлана Михайлівна, асистент, кафедра лісового та садово-паркового господарства. Email: pidkhovna_s@ukr.net Тиманська Оксана Богданівна, ст. викладач, кафедра лісового та садово-паркового господарства. Email: oksanaburak@ukr.net

Гринюк Юрій Григорович, канд. с.-г. наук, доцент, ст. наук. співробітник, кафедра лісового та садово-паркового господарства. Email: hrynyuk@ukr.net

Цитування за ДСтУ: Кузьович В. С., Бідолах Д. І., Підховна С. М., Тиманська О. Б., Гринюк Ю. Г. Впорядкування зелених насаджень та благоустрій території Лановецького зооботсаду в Тернопільській області. Науковий вісник НлтУ України. 2020, т. 30, № 3. C. 18-23.

Citation APA: Kuziovych, V. S., Bidolakh, D. I., Pidkhovna, S. M., Tymanska, O. B., \& Hrynyuk, Yu. G. (2020). Management of green plantings and organization of Lanivtsi zoo-botanical garden territory in the Ternopil Region. Scientific Bulletin of UNFU, 30(3), 18-23. https://doi.org/10.36930/40300303 
дарських, організаційних і регулятивних заходів із благоустрою та озеленення. Зоологічний парк створено ще в 1977-1979 рр. завдяки ініціативі місцевого природознавця К. А. Чернеця та мешканців району на базі частини території Лановецького парку культури і відпочинку (юридичний статус парку присвоєно рішенням № 303 Тернопільської обласної ради від 26 грудня 1991 р.) [10].

Зоологічний парк місцевого значення "Лановецький зооботсад" визнано об'єктом природно-заповідного фонду і відповідно перебуває під охороною, як національне надбання (рішення Тернопільської облради № 90 від 25 квітня 1996 р. "Про внесення змін і доповнень до мережі територій та об'єктів природно-заповідного фонду області..."). Зоологічний парк є об'єктом власності територіальної громади у м. Ланівці, для якого встановлено особливий режим використання, охорони та збереження згідно з чинним законодавством. Балансоутримувачем зооботсаду є Лановецька міська рада, відповідно до ст. 12 Закону України "Про природно-заповідний фонд України", яка провадить управління парком відповідно до Положення про нього [10].

Зоологічні парки в Україні потребують поєднання природоохоронної і рекреаційної діяльності, тому наукові дослідження в цьому напрямі є актуальними на сьогодні. Архітектурно-просторова організація Лановецького зооботсаду повинна мати можливість реалізувати пізнавальні, виховні і розважальні цілі відвідувачів, а також можливість відпочинку. Для цього експозиції варто поєднувати з різними навчальними, інформаційними центрами та місцями відпочинку, що дасть змогу зооботсаду зайняти важливий сегмент в рекреаційній індустрії.

Аналіз світового досвіду організації роботи зоологічних парків свідчить про те, що вони мають важливе природоохоронне, науково-просвітницьке та рекреаційно-туристичне значення. Проте у вітчизняних наукових публікаціях недостатньо інформації щодо особливостей організації діяльності зоологічних садів, як рекреаційно-туристичних об'єктів.

Об'єкт дослідження - впорядкування зелених насаджень та благоустрій території парку.

Предметом дослідження є методи і засоби впорядкування зелених насаджень та благоустрій території парку, що дасть змогу здійснити планувальну структуру Лановецького зооботсаду в Тернопільській області.

Мета дослідження полягає у комплексному аналізі зелених насаджень Лановецького зооботсаду та розроблення низки заходів з їх упорядкування та благоустрою території.

Для досягнення зазначеної мети поставлено такі оcновні завдання дослідження: визначити і проаналізувати таксономічний склад насаджень парку, оцінити його 3 точки зору фітосанітарного, якісного та естетичного стану, встановити типи садово-паркових ландшафтів об'єкта, розробити проектні пропозиції з реконструкції парку.

Наукова новизна дослідження полягає в тому, що було вперше розроблено видовий склад насаджень території парку, наведено його фітосанітарну, естетичну та якісну характеристики, визначено типи садово-паркових ландшафтів Лановецького зооботсаду.

Практична значущість отриманих результатів зводиться до того, що їх можна використати для створення електронного макету-основи території 3 нанесеною деревно-кущовою рослинністю, що дасть змогу змоде- лювати у комп'ютерній програмі часові зміни та перетворення внаслідок реконструкції зоологічного парку.

Матеріали і методи дослідження. Інвентаризацію зелених насаджень виконували відповідно до чинної Інструкції з інвентаризації зелених насаджень у населених пунктах України [9].

Види деревних і чагарникових рослин встановлювали за визначником Н. М. Андронова [2]. Таксономічний склад дендроценозів визначали методом маршрутних обстежень. Для аналізу ландшафтів використовували класифікацію садово-паркових ландшафтів Л. І. Рубцова [13]. Фітосанітарний стан деревно-кущових видів рослин оцінювали за зовнішніми морфологічними ознаками. Інвентаризаційні роботи зі встановлення стану зелених насаджень виконували у весняний період. Візуально оцінювали ступінь пошкодження та ураження листя за відомою шкалою Красинського. Для оцінки стану рослин у парковому ценозі використовували згадану шкалу у модифікації Ю. 3. Кулагіна. Для діагностики життєвого стану дендроценозу користувалися шкалою категорій В. А. Алексєєва [1].

Під час розрахунку індексу стану паркового дендроценозу за кількістю дерев застосовували таку формулу:

$$
L n=\frac{100 n_{1}+70 n_{2}+40 n_{3}+5 n_{4}}{N},
$$

де: $L n$ - відносний життєвий стан дендроценозу, розрахований за кількістю дерев; $n_{1}-$ кількість здорових, $n_{2}-$ ослаблених, $n_{3}$ - сильно ослаблених, $n_{4}$ - дерев, що відмирають на пробній площі; $N$ - загальна кількість дерев (враховуючи сухостій) на пробній площі.

Для аналізу та опису стану рослин визначали біометричні показники: діаметр та висоту дерев, а також стан їх життєвості, встановлений за методикою Інструкції з інвентаризації зелених насаджень у населених пунктах України [9].

Використання методики В. А. Алексєєва, яка базується на характеристиці особливостей крони, дає змогу оцінити не тільки кумулятивні прояви рослин у процесі конкурентної боротьби за життєвий простір та абіотичні фактори довкілля (світло, вологу, мінеральне живлення), але й ознаки ослаблення дерев, пошкоджених будь-якими антропогенними чинниками та іншими явищами. Згідно з цією шкалою дерева парку розподіляють за п'ятьма категоріями. 3 огляду на те, що обстеження парку здійснювали у весняний період, коли листя на листопадних рослинах ще не могло бути індикатором якості стану дерева, ми застосували дещо спрощену методику оцінки, поділивши дерева на три категорії стану (як це, зрештою, вимагає "Інструкція з інвентаризації зелених насаджень у населених пунктах України"): "добрий", "задовільний" або "незадовільний".

Для дослідження біометричних показників рослин використовували як традиційне інструментальне забезпечення (висотомір, мірна вилка), так і сучасне - пристрій глобального позиціювання GPS (Garmin GPSMap 64S), геоінформаційні системи ГIC (ArcGis 9.2) та матеріали дистанційного зондування Землі (ДЗ3), що знаходяться у вільному доступі. Так, інформацію про місце розташування кожного дерева отримували за допомогою GPS-приймача 3 наступним іï коригуванням за матеріалами ДЗ3 у ГІС. За результатами виконаної роботи створено геоінформаційну базу даних деревно-кущової рослинності, у якій координати іії розташування поєднували з інформацією за видовими і фітосанітарними ознаками та основними біометричними показниками. Це, 
відповідно, дало змогу перевести ії у цифровий формат із створенням можливості автоматизованого опрацювання даних і на картографічних матеріалах. Такий підхід дав змогу створити 3D візуалізацію території зооботсаду у спеціалізованій програмі Realtime Landscaping Architect 16.

Аналіз літературних джерел. Перспективні напрями рекреаційної діяльності зоологічних садів висвітлено у низці наукових публікацій. Науковці Н. Т. Більдер і К. К. Вознюк сформулювали ідею і концепцію рестайлінгу комплексу елементів візуальної ідентифікації Харківського зоопарку і виявили тенденції у формуванні візуальної ідентичності сучасних зоопарків [3]. У публікації Л. П. Коваленко і А. В. Жупаненко наведено маркетинговий аналіз стану зоологічних парків України [7]. Значення зоологічних парків у збереженні рідкісних і видів тварин, що зникають, дослідили Л. С. Скуратова [14], Ж. Г. Стегней і М. С. Ковзусь [15]. А. Олівей і К. Джансен здійснили наукові дослідження щодо ролі канадських зоопарків у збереженні видів тварин, які перебувають під загрозою зникнення [11]. У науковій праці А. Бедворт і А. Брайман наводять аргумент, що сучасні зоопарки зазнають кардинальних змін, зокрема триває тенденція до їх діснеїзації [16]. Н. Карр і С. Коен досліджували трансформацію зоопарків у напрямі розширення їх функцій за оптимального поєднання природоохоронної та рекреаційної діяльності зоологічних парків [4]. Природо-охоронець Дж. Маллінсон наголосив на важливості стратегії розвитку зоопарків як центрів збереження диких тварин [8]. Опис зоопарків, як окультурених ландшафтів, що потребують збереження та трансформації, виконали Б. С. Холлмен і М. Бенбоу [6]. Освітню і економічну цінність зоопарків дослідив науковець С. Фуллєр [5].

У зазначених вище літературних джерелах досліджено різні особливості функціонування зоологічних парків. Проте, незважаючи на велику кількість наукових публікацій щодо забезпечення діяльності зоопарків, питання їх трансформації відповідно до ландшафтноархітектурних вимог $\epsilon$ актуальними на цей час та потребують наукових досліджень і практичних напрацювань.

\section{Результати дослідження}

Унаслідок виконаної роботи ми отримали інформацію про видовий склад та фітосанітарний стан деревно-кущової рослинності на території Лановецького зооботсаду.

Особливої уваги заслуговує тваринний світ зоологічного саду. Раніше у зоопарку в природних умовах проживало 61 видів тварин, серед яких - 10 видів ссавців (олень плямистий (Cervus nippon), лисиця звичайна (Vulpes vulpes), борсук звичайний (Meles meles), лебідьшипун (Cygnus olor), лелека білий (Ciconia alba), крижень (Anas platyrhynchos) та ін.); 39 видів птахів (зокрема екзотичні - казарка канадська, павич звичайний, курка пухова); 1 - плазун, 6 - земноводних, 3 - риб та 2 види молюсків. На сьогодні більшу частину колекції тварин втрачено і починаючи з 90-х років ХХ ст., після припинення фінансування закладу, тварин ставало щораз менше. Зараз тут живуть тільки дикі свині, бобри, ондатри, їжаки, кілька видів декоративних птахів, зокрема декоративні кури, цесарки і фазани, дикі качки різних видів. 3 рідкісних, занесених до "Червоної книги України", видів тварин на території парку постійно або періодично перебувають такі: горностай, тхір лісовий і степовий, видра річкова, кутора мала та ін. 3 птахів - боривітер, шуліка чорний, лунь лучний, сова болотяна, баранець великий, очеретянка прудка та ін.

За результатами інвентаризації зелених насаджень зоологічного парку "Лановецький зооботсад" (рис. 1) виявлено 69 видів і форм дендрофлори, основні з яких: ясен звичайний, клен гостролистий, липа серцелиста, тополя чорна, береза повисла, тополя тремтлива, вільха чорна, робінія псевдоакація, ялина європейська, клен ясенелистий, клен-явір, верба ламка, туя західна, горіх грецький. Багато у парку самосійного підросту другорядних малоцінних видів: клена ясенелистого, аличі, ясена зеленого та кущових видів.

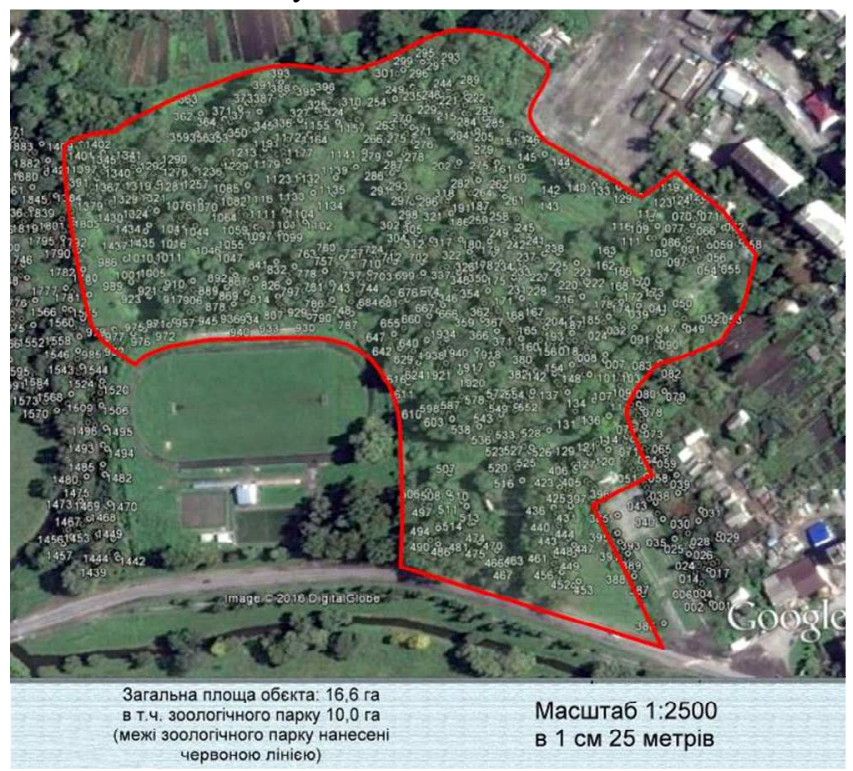

Рис. 1. Геоінформаційний план інвентаризації зелених насаджень для розроблення проекту організації території зоологічного парку м. Ланівці Тернопільської області

Панівні види другого ярусу, сформованого здебільшого $з$ молодих насаджень, - горобина звичайна, граб звичайний, клен ясенелистий, алича, туя західна та інші види дерев і кущів, які представлені тут у незначній кількості. Недостатній у зоологічному парку асортимент кущів, що є наслідком надмірної загущеності і високої зімкнутості паркових насаджень i, як результат браку світла на поверхні грунту. Через це під наметом слабо розвинене трав'яне вкриття.

Як свідчать дані оцінки фітосанітарного стану деревної рослинності (рис. 2), переважна кількість дерев належить до категорій стану "добрий" (55 \% від загальної кількості деревних рослин). Стану "задовільний" відповідає $23 \%$ та "незадовільний" - $22 \%$.

За кількістю деревних рослин показник відносного життєвого стану паркового дендроценозу становить $84 \%$, що відповідає оцінці "добре". Найкращий життєвий стан демонструють такі види, як ясен звичайний, береза повисла, вільха чорна, клен-явір, туя західна, клен гостролистий, ясен зелений, клен ясенелистий, горіхи чорний i маньчжурський, робінія псевдоакація, ялиця біла, липи серцелиста і широколиста. У незадовільному стані перебувають такі види, як тополя чорна (87\% від загальної кількості дерев виду), граб звичайний - $31 \%$, осика - $56 \%$, верба біла - $26 \%$, клен ясенелистий - $23 \%$ і верба ламка - $50 \%$. Для комплексної оцінки деревних насаджень парку оцінювали також зміни зовнішнього вигляду дерев. Серед деревних насаджень парку виявлено 324 дерева із фаутами (15,5\% від усіх дерев). 


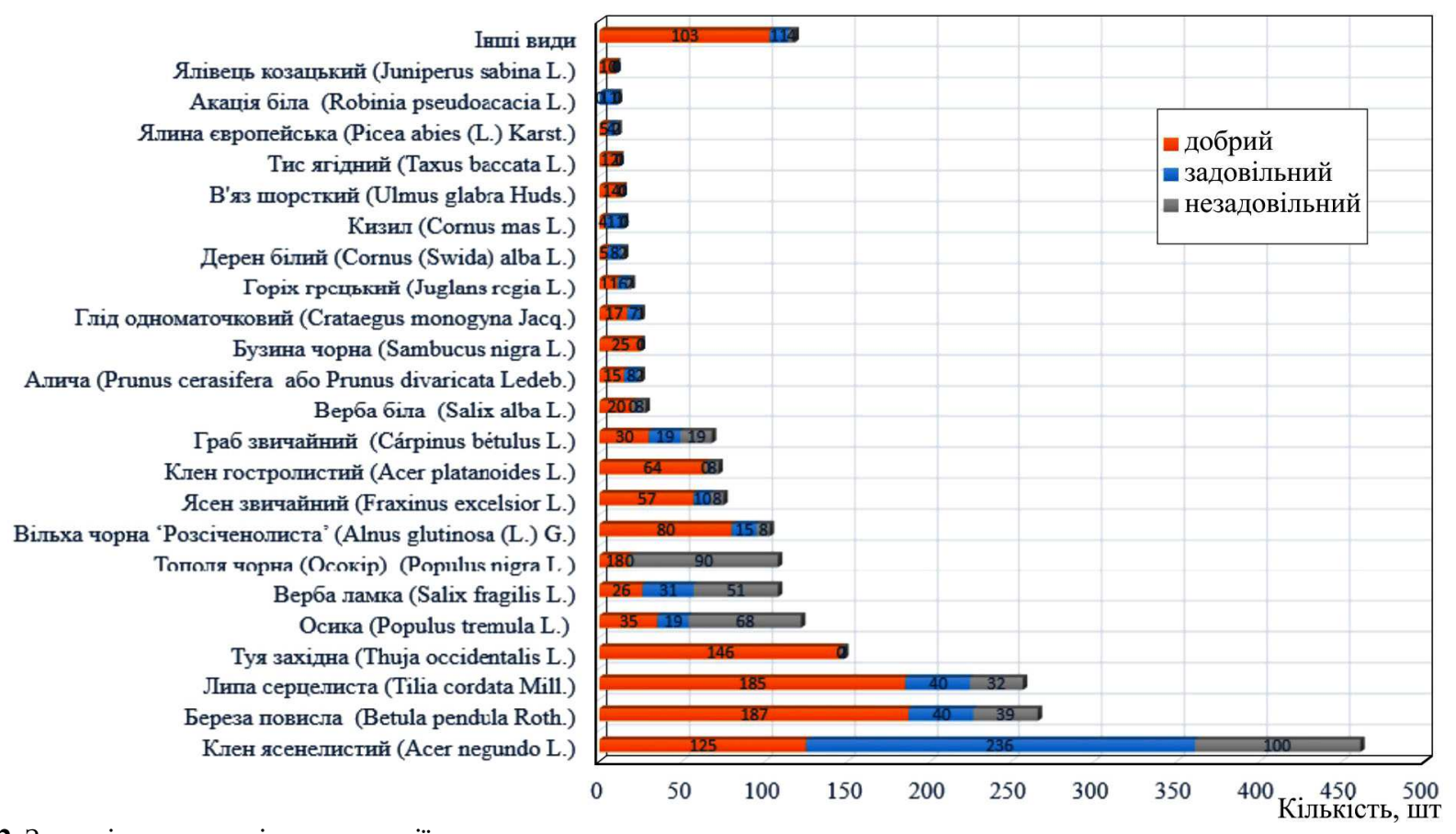

Рис. 2. Зведені результати інвентаризації деревно-кущових рослин

Оцінка ландшафтів за Рубцовим свідчить про тісну прив'язку визначених типів садово-паркових ландшафтів до проведеного зонування території парку. Рекреаційна зона представлена лісовим ландшафтом, який передбачається перетворити в парковий. Відкриті (партерні) ділянки парку (зони культурно-просвітницьких заходів та активного відпочинку) представлені лучним типом. Експозиційна зона містить елементи садового та фрагменти (альпінарії і рокарії) альпійського типів садово-паркових ландшафтів.

Функціональне зонування території зоологічного парку здійснено відповідно до Закону України "Про природно-заповідний фонд України", Положення про установу природно-заповідного фонду та Положення про Зоологічний парк.

Обговорення результатів дослідження. Унаслідок опрацювання наукових літературних джерел встановлено, що різні автори дослідили такі особливості організації зоологічних садів, як: перспективні напрями їх рекреаційної діяльності (А. Бедворт, А. Брайман, Н. Карр, С. Коен, Б. С. Холлмен і М. Бенбоу), тенденції формування візуальної ідентичності (Н. Т. Більдер і К. К. Вознюк), маркетинговий аналіз стану даних об'єктів (С. Фуллєр, Л. П. Коваленко і А. В. Жупаненко), значення зоологічних парків у збереженні рідкісних і видів тварин, що зникають (Л. С. Скуратова, Дж. Маллінсон, Ж. Г. Стегней і М. С. Ковзусь, А. Олівея і К. Джансен). Існують також рекомендації щодо оформлення архітектурно-планувальної структури, функціонального зонування, розміщення експозиційних маршрутів для територій зоопарків у навчальній літературі [7, с. 479].

Проте наукові розробки практичних рішень щодо ландшафтно-архітектурного оформлення зооботанічних садів за результатами аналізу стану їх зелених насаджень майже відсутні у наукових працях. Зважаючи на це подібні дослідження актуальні та мають теоретикопрактичне значення.

Для впорядкування зелених насаджень та обгрунтування заходів із благоустрою території Лановецького зооботсаду здійснено його комплексний аналіз. Під час натурного обстеження паркової території встановлено, що парк перебуває у незадовільному стані та потребує регулятивних заходів 3 його покращення. Особливу увагу потрібно звернути на малоцінні групи деревних рослин, всихаючі та сухостійні дерева, які істотно знижують декоративні якості зелених насаджень та порушують загальну композицію паркових насаджень.

Для забезпечення реалізації природоохоронних, науково-просвітницьких і рекреаційно-туристичних функцій об'єкта дослідження ми використали результати аналізу стану зелених насаджень Лановецького зооботсаду, щоб розробити низку заходів із їх упорядкування та благоустрою території.

Так, архітектурно-просторова організація зоопарку повинна мати можливість реалізувати пізнавальні, виховні і розважальні цілі відвідувачів, а також можливість відпочинку. Для цього при експозиціях проектують різні навчальні, інформаційні центри та місця відпочинку. Для підвищення рекреаційної привабливості ми запроектували низку заходів із благоустрою теритоpiï, a саме: створення місць для коротко- і довготривалого відпочинку відвідувачів; підвищення естетичності оформлення території біля будинку для еколого-просвітницької діяльності; влаштування території співочого поля для покращення якості організації культурно-масових заходів; збагачення видового складу рослин декоративними кущами; покращення квітникового оформлення території парку; заходи щодо реконструкції двох острівців; улаштування спортивного майданчика для занять спортом; планування експозиційної зони із врахуванням ландшафтно-архітектурних принципів; встановлення інформаційних стендів; організацію дорожньо-стежкової мережі; благоустрій водойм; встановлення малих архітектурних форм; влаштування освітлення території.

Функціональне зонування території зоологічного парку виконано відповідно до Положення про Зоологічний парк. Проектні пропозиції відображено на генеральному плані організації території зоологічного парку (рис. 3) та у вигляді тривимірної візуалізації (рис. 4). 

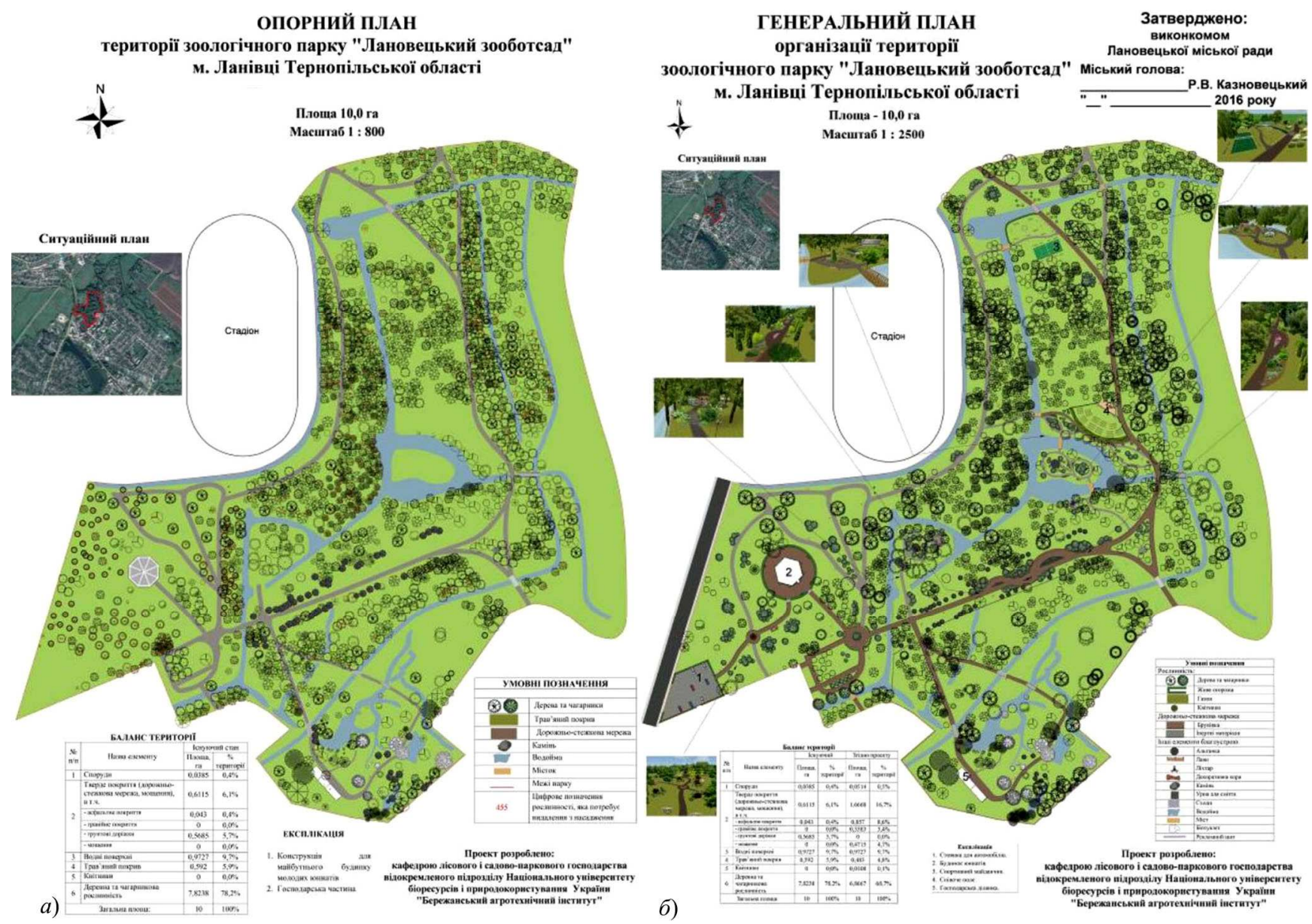

Рис. 3. Вихідні картографічні матеріали
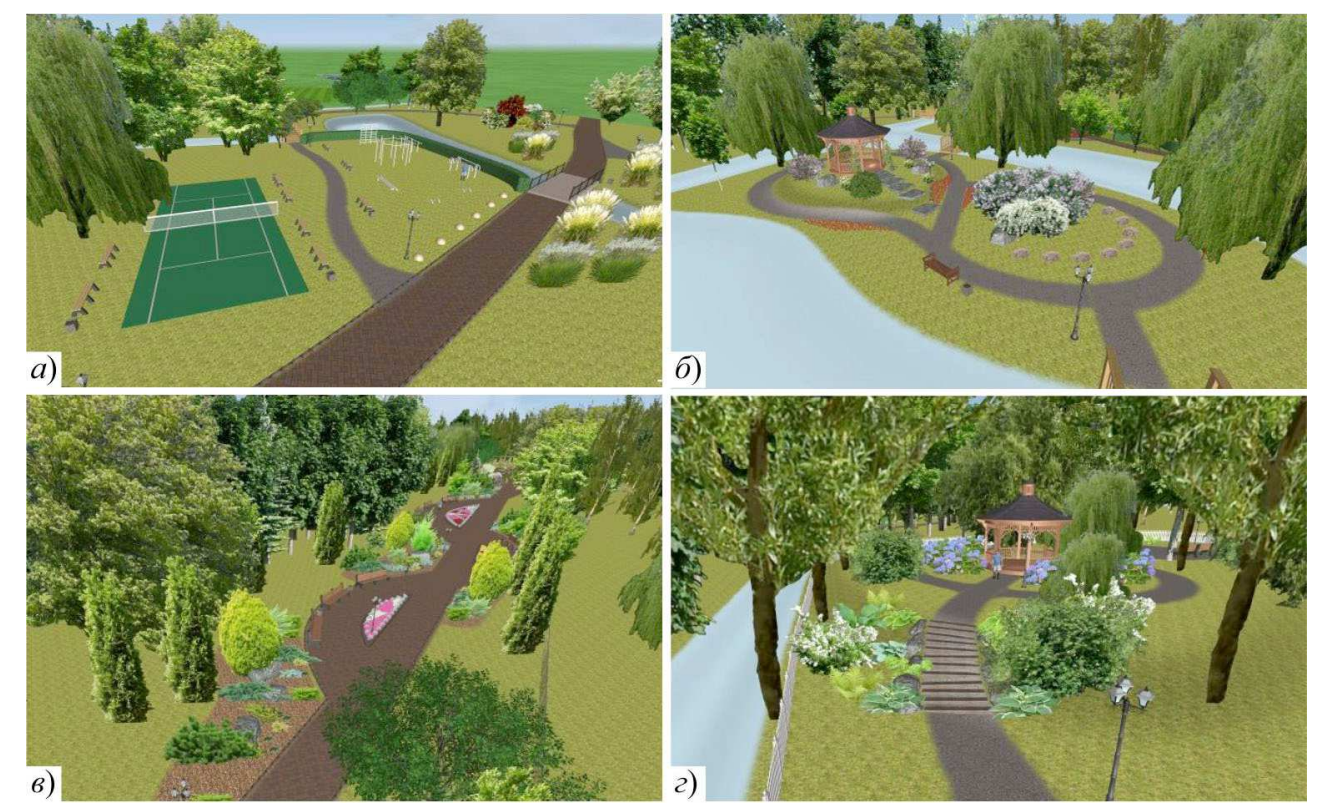

Pис. 4. Проектне 3D-моделювання території Лановецького зооботсаду

Експозицію зоосаду доцільно організовувати за сучасними екологічним експозиційними принципами: зближення місць оселення фауни, яка у природі живе в однакових умовах або поєднується відповідно до способу життя. Умови утримання тварин у неволі потрібно максимально наближати до природних, а також застосовувати сучасні способи експонування з показом тварин невеликими групами.

Ландшафтна організація експозиційної зони побудована так, щоб штучно створені елементи середовища існування тварини були максимально наближеними до природних умов. Покриття доріжок в експозиційній зоні передбачається 3 природних матеріалів, відповідно до стилю експозиції.

Переважна частина експозиційних споруд на території зоосаду згруповані у невеликі комплекси, до складу яких варто віднести не тільки споруди для утримання та демонстрації тварин у неволі, але й будівлі, які створюють комфортні умови для огляду експозицій. Асортимент рослинності, запропонованої для удосконалення зелених насаджень зоологічного парку, налічує 41 найменування декоративних листяних і хвойних кущів. 
Для того, щоб повернути парку належний вигляд та здатність виконувати покладені на нього функції, необхідно найближчим роками виконати запланований обсяг робіт з реконструкції парку, основну частину з яких передбачено виконати цього року. Реалізація проектних пропозицій забезпечить належний рівень функціонування зоологічного парку "Лановецький зооботсад".

\section{Висновки:}

1. Положенням про зоологічний парк місцевого значення "Лановецький зооботсад" передбачено використання території в наукових, оздоровчих, рекреаційних і екологопросвітницьких цілях. Парк має стати ініціатором проведення екологічних акцій та їх осередком.

2. За результатами аналізу стану зелених насаджень на території об'єкта з'ясовано, що на цей час потрібно здійснити комплекс заходів з відновлення естетичного вигляду насаджень, забезпечення належного рівня подальшого їх функціонування та створення нових декоративних деревно-кущових і квітникових композицій.

3. Унаслідок виконаних наукових досліджень встановлено та проаналізовано дендрологічний склад паркових насаджень, виконано фітосанітарну, якісну та естетичну його оцінку, виділено типи садово-паркових ландшафтів об'єкта, а також розроблено проектні пропозиції з реконструкції парку у вигляді пояснювальної записки, картографічного матеріалу і тривимірної моделі території.

4. Створення електронного макету-основи території 3 нанесеною деревно-кущовою рослинністю дало змогу змоделювати у комп'ютерній програмі часові зміни та перетворення внаслідок реконструкції зоологічного парку.

\section{References}

1. Alekseev, V. A. (1989). Diagnosis of the vital state of trees and stands. Lesovedenie, 4, 51-56. [In Russian].

2. Andronov, N. M. (1974). Key to woody plants by leaves. Leningrad: Izdatelstvo Leningradskogo universiteta. [In Russian].

3. Beadworth, A., \& Bryman, A. (2001). The wild animal in late modernity: the case of the Disneyization of zoos. Tourist studies, 1, 83-104. https://doi.org/10.1177/146879760100100105
4. Bilder, N. T., \& Vozniuk, K. K. (2018). Zoo visual identity restyling. Traditions and innovations in the higher architectural-artistic education, 3, 27-36. http://doi.org/10.5281/zenodo.1443092

5. Carr, N., \& Cohen, S. (2011). The Public Face of Zoos: Images of Entertainment, Education and Conservation. A Multidisciplinary Journal of The Interactions of People \& Animals, 24(2), 175-189. http://doi.org/10.2752/175303711X12998632257620

6. Fuller, S. S. (2010). Economic Impact of Zoo and Aquarium Operations And Construction Spending. Retrieved from: https://assets.speakcdn.com/assets/2332/aza_economic_impact_report_2010.pdf

7. Gorokhov, V. A. (2005). Green nature of the city. Textbook for high schools (the 2nd edition supplemented and revised). Moscow: Architecture-S, 592. [In Russian].

8. Hallman, B. C., \& Benbow, M. (2006). Naturally Cultural: the zoo as cultural landscape, Can. Geogr., 50(2), 256-264. https://doi.org/10.1111/i.0008-3658.2006.00139.x

9. Instruction on inventory of green spaces in settlements of Ukraine. Approved by Order No. 226 of the State Committee for Construction, Architecture and Housing from 24.12.2001. [In Ukrainian].

10. Kovalenko, L.P., \& Zhupanenko, A. V. (2012). Marketing analysis of zoological parks of Ukraine and features of their use for tourist purposes. Bulletin of Socio-Economic Research, 1(44), 214-218. [In Ukrainian].

11. Mallinson, J. C. (2003). A sustainable future for zoos and their role in wildlife conservation. Hum. Dimens. Wildlife, 8(1), 59-63. https://doi.org/10.1080/10871200390180154

12. Olivea, A., \& Jansen, K. (2017). The contribution of zoos and aquaria to Aichi Biodiversity Target 12: A case study of Canadian zoos. Global Ecology and Conservation, 10, 103-113. https://doi.org/10.1016/j.gecco.2017.01.009

13. Regulations on zoological park of local importance "Lanovets Zoo". (2015). [In Ukrainian].

14. Rubtsov, L. Y., \& Laptev, A. A. (1969). Handbook of green building. Kyiv: Budivelnyk. [In Russian].

15. Skuratova, L. S. (2010). The role of zoos in preserving the biological diversity of the Earth. Bulletin of Altai State Technical University I. I. Polzunova, 1-2, 146-148. [In Russian].

16. Stehnei, Zh. H., \& Kovzus, M. Ye. (2010). The role of zoological parks in the conservation of rare and endangered animal species. Naukovyi visnyk LNUVMBT imeni S. Z. Gzhytskoho, 2(44), 287290. [In Ukrainian].

V. S. Kuziovych, D. I. Bidolakh, S. M. Pidkhovna, O. B. Tymanska, Yu. G. Hrynyuk

Berezhany Agrotechnical Institute of National University of Life and Environmental Sciences of Ukraine, Berezhany, Ukraine

\section{MANAGEMENT OF GREEN PLANTINGS AND ORGANIZATION OF LANIVTSI ZOO-BOTANICAL GARDEN TERRITORY IN THE TERNOPIL REGION}

The Lanivtci zoo-botanical garden is a part of the Nature Reserve Fund of Ukraine, one of the unique laboratories for the conservation of biodiversity, natural heritage conservation, and a museum of wildlife which has scientific and educational importance. The study tested modern methods for the inventory of trees and shrubs of this zoo-botanical garden. We used the GPSreceiver to get the information about the position of each tree and shrub, and then the spatial information was transferred to GIS and modeled on the basis of remote sensing materials in a computer program such as Realtime Landscaping Architect 16. As a result, we get the project proposals for landscape and architectural design of the zoo area in the form of cartographic materials and 3dimensional layout in the computer program. The creation of an electronic layout-basis of the territory with trees and shrubs allowed modeling in the computer program changes and transformations resulting from the reconstruction of the zoo. Such new approaches have been worked out on ways of conducting a comprehensive assessment of the landscape planning structure of the territory. The taxonomic composition of dendrocenoses was provided and the types of landscape gardens of the object were determined during the inventory. The study analyzed the state of plantations of the park. Its assessment realized in terms of phytosanitary, qualitative, and aesthetic state. Consequently, the results of the trees and shrubs inventory of the Lanivtci zoo-botanical garden have shown 69 species and forms of dendroflora available here. According to the assessment of the phytosanitary situation of greenery, the overwhelming number of trees belong to the categories of "good" (55\% of the total number of plants), "satisfactory" (23\%) or "unsatisfactory" $(22 \%)$. We found 324 defect trees (15.5\% of quantity). As a result, we estimate the living condition of the park like "good", according to the number of trees in good condition $(84 \%)$. Moreover, as a result of this study we got the information about the animal world of the zoological part of this park. The fauna is represented by quite numerous animals and birds listed in the Red Book. An analysis of the state of green plantations on the territory of the site shows that it is now necessary to perform a set of measures in order to restore the aesthetic appearance of plantations, to ensure an adequate level of their further functioning and to create new decorative tree and shrub and flower compositions.

Keywords: inventory; 3-dimensional layout of plantations; zoo-botanical garden; taxonomic composition. 